\author{
Vitaliy Zatylnyy \\ Uniwersytet Łódzki \\ vitzat@ukr.net
}

\title{
ZNACZENIE HISTORII SLOWIANOBULGARSKIEJ PAISIJA CHILENDARSKIEGO DLA KRYTYKI HISTORIOGRAFICZNO-LITERACKIEJ I JEJ RECEPCJA W PERSPEKTYWIE DIACHRONICZNEJ
}

\section{Wprowadzenie}

W prężnie rozwijającym się świecie powstają nowoczesne koncepcje badań różnych zjawisk lub tematów zupełnie różniące się od badań z poprzednich epok. Zupełnie innymi, nowoczesnymi metodami posługują się $\mathrm{m}$. in. historycy, diachronicznie analizując pewne fakty. Nierzadko krytykują, a nawet sceptycznie oceniają dzieła swoich poprzedników. Czy może być aktualna w XXI w. Historia słowianobutgarska Paisija Chilendarskiego (dalej - Historia SB), której powstanie wiązało się z brakiem szerokiej literatury źródłowej i możliwości sprawdzania autentyczności faktów? Bez wątpienia, nadal jest aktualna, niezastąpiona i ważna nie tylko dla Bułgarów, ale również innych narodów słowiańskich. Postaram się udowodnić powyższą tezę przez analizę tego dzieła wkazując, czym dla ówczesnej Bułgarii było dzieło Paisija, mimo jego pewnych nieścisłości faktograficznych, i czym jest obecnie. Sam Paisij, jak również autorzy odpisów jego dzieła, w ówczesnych realiach nie mieli wątpliwości wobec opisywanych faktów historycznych.

Warto podkreślić, że tzw. pamięć historyczna jest cechą tożsamości narodowej i katalizatorem rozwoju. Bez tej pamięci i w ogóle historiografii naród nie może wykazać się silną państwowością. Unikatowy przykład walki o swoje silne państwo poprzez docenienie własnej historii znajdujemy w Bułgarii, w jej najtrudniejszym okresie (niewoli osmańskiej), kiedy nieoczekiwanie pojawił się manifest i narodowy program rozwoju państwa, które wbrew ówczesnym potęgom politycznym miało wszystkie historyczne podstawy, by istnieć i funkcjonować. Takim manifestem, oczywiście, była Historia SB (1762). To nie tylko księga o bułgarskiej i ogólnosłowiańskiej przeszłości, napisana w duchu panslawistycznym, ale również dzieło dla następnych pokoleń. Nieprzypadkowo głównym bohaterem dzieła jest cały naród bułgarski, któremu zresztą autor zadedykował swoją historię. 


\section{Problematyka recepcji powieści w perspektywie diachronicznej}

Dzieło Paisija liczy ponad 250 lat. Od czasu ukazania się do dzisiaj jest popularne zwłaszcza w kulturach i historiografiach słowiańskich. Jego recepcja różni się w zależności od epok i miejsc, w których jest komentowana, ale niezmienna zostaje aktualność Historii $S B$, idea wnioskowania z przeszłości i motyw dumy narodowej. Dla Bułgarów to dzieło jest i zawsze zostanie świątynią narodową. Profesor Bożydar Dimitrow w opracowaniu/przedmowie do nowego wydania utworu tak charakteryzuje bułgarską recepcję Historii $S B$ :

Всички знаеха, че Историята няма вече научна или художествена стойност, и се покланяха всъщност на една национална реликва, на една програма за национално, духовно и политическо възраждане на българския народ и българската държава, която се осъществи точно по повелите на Паисий в следващите десетелетия [Паисий Хилендарски 2004: 8].

Pierwotne znaczenie Historii $S B$ jest widoczne chociażby w tym, że to też dzięki Paisijowi przebudziła się świadomość narodowa i pragnienie wyzwolenia swojej nieszczęśliwej Ojczyzny po wojnie rosyjsko-tureckiej 1877-1878. Oryginał Paisija i jego późniejsze odpisy przygotowywały czytelnika do radykalnych zmian w Bułgarii, podkreślały unikatowość bułgarskiego narodu wśród innych narodów ówczesnej Europy, broniły prawa do posiadania własnego dziedzictwa narodowego. Dlatego utwór był pozytywnie i przekonująco odbierany zarówno przez lud, który dzięki Paisijowi zyskał wiele nowych istotnych informacji, jak i przez oświeconych Bułgarów (przede wszystkim, osób duchownych), którzy tworzyli późniejsze odpisy Historii $S B$.

Istnieje około 70 odpisów dzieła. Pierwszy odpis jest datowany na $1765 \mathrm{r}$. Dokonał go pop Stojko Władysławow, a później biskup Sofroniusz Wraczański [Dąbek-Wirgowa 1980: 67-69]. Dzięki temu i innym odpisom dzieło Paisija błyskawicznie rozpowszechniło się wśród narodu bułgarskiego. Ciekawe, że autorami odpisów były nie tylko osoby duchowne, a również nauczyciele, pisarze, nawet rzemieślnicy, którzy uświadamiali wielkość słowa autora Historii SB i jego misji. Siła wpływu Paisija była tak potężna, że kopiści jego dzieła dodawali swoje opinie. Na przykład, w odpisie z roku 1772 mnich Makarij z Chilendaru napisał:

Прочитах сию историю и разумех, что есть писано в нея. И вие потрудите са, братия, та я прочитети, да ви буди на ползу, болгаром похвала [Ангелов 2017].

Pierwsze drukowane wydanie Historii $S B$ ukazało się stosunkowo późno - dopiero w 1914 r. dzięki Bułgarskiej Akademii Nauk. Oryginał dzieła został przygotowany do druku przez Jordana Iwanowa i opatrzony opracowaniem. $\mathrm{W}$ wydaniu również umieszczono zdjęcia miejsc, związanych w powstaniem $\mathrm{Hi}$ storii SB [Иванов 1914]. Kolejne wydania dzieła pojawiły się dopiero na przełomie XX i XXI w. w wydawnictwie Uniwersytetu Sofijskiego.

$\mathrm{Z}$ biegem czasu Historię $S B$ odbierano nie jako małą encyklopedię bułgarskich dziejów, a jako publicystyczny, przepełniony emocjami tekst, który powoli 
stawał się relikwią narodową oraz źródłem inspiracji dla pisarzy i historyków następnych generacji. W opracowaniu/przedmowie do wydania Historii $S B$ w ramach biblioteki dla bułgarskich uczniów czytamy:

[Този труд] целият е изпълнен с патриотичен патос, историческото четиво се е превърнало в пламенна публицистика [Паисий Хилендарски 1989: 5; przedmowa, opracowanie].

W taki sposób dzieło jest odbierane do dziś zarówno przez zwykłych czytelników, jak i badaczy. Sam fakt powstania takiego utworu wyklucza krytykę i dyskusję na temat pewnych uchybień i domniemań Historii $S B$, które fragmentarycznie zostaną wymienione niżej. Takiego zdania byli przedstawiciele Bułgarskiego Odrodzenia Narodowego. Podkreślali oni nieocenioną wartość tego dzieła, mimo jego nieścisłości. Georgi Rakowski potwierdza ograniczone możliwości Paisija:

Благоговейни отец Паисий, ако не е писал по-обширно о тому, то обстоятелства не му са допущали ради духовного му чина, но пак доволно е писал и негова ръкопис е принесла голяма полза, приписвана от тогашни българи [Арнаудов 1962: 120-122].

Bułgarski badacz Marin Drinow w taki sposób wypowiada się o Paisiju:

Списанието на отца Паисия от научна страна няма твърде голяма цена, но ние и нямаме никакво право да искаме от него строга историческа критика [Дринов 1871: 3].

O wielkiej sprawie Paisija przypomina Iwan Wazow w Epopei zapomnianych. Apeluje do odbiorcy, przede wszystkim, bułgarskiego, z okazji 120-lecia ukazania się Historii $S B$, ponieważ jako Bułgar czuje się zobowiązany wykonać jego testament. W Epopei zapomnianych przypisuje Paisijowi następujące słowa:

\footnotetext{
От днеска нататък българският род / история има и става народ! ${ }^{1}$
}

W sposób poetycki w imieniu Paisija Wazow/narrator streszcza zawartość Historii $S B$ : wymienia bułgarskich władców, sakralizuje język bułgarski, wskazuje na historyczne granice Państwa Bułgarskiego. Recepcję dzieła Paisija charakteryzuje następująco:

$$
\begin{gathered}
\text {...фърляше тайно през мрака тогаз / } \\
\text { най-първата искра в народната свяст². }
\end{gathered}
$$

Inny wybitny działacz społeczny epoki powyzwoleniowej i literat Petko Sławejkow też wypowiadał się o recepcji dzieła Paisija, które wywarło na niego ogromny wpływ. Mimo nowych tendencji w myśli społecznej i sprzyjających warunków po

1 И. Вазов, Епопея на забравените, http://www.slovo.bg/showwork.php3?AuID=14\& WorkID=914\&Level=2 [dostęp: 1.12 .2017$]$.

${ }^{2}$ Tamże. 
wyzwoleniu, bułgarska inteligencja odwoływała się do Paisija i jego sprawy. Można stwierdzić, że w taki sposób Sławejkow został kontynuatorem jego idei:

...по прочтении этой истории я стал думать о том, как спасти свой народ, то есть о том, как вдохнуть в него патриотизм. Чтение и переписка этой «Истории» дали другое направление моим желаниям и моей деятельности [Ангелов 2017]³.

W dość ciekawy i wszechstronny sposób postać Paisija i dzieło jego życia przedstawia Dymitr Talew w powieści historycznej Хилендарският монах (1962). Jego bohater jest obdarzony nie tylko talentem historiografa, ale wykazuje się nieprzeciętną postawą moralną, potrafi całkowicie poświęcić się swojej Ojczyźnie, dąży do swojego celu i w końcu go osiąga. Utwór można uznać też za powieść społeczno-obyczajową. Występują w niej - obok postaci historycznych - bohaterowie stworzeni przez Talewa. Postać Paisija została przybliżona polskim czytelnikom w 1975 r., kiedy ukazała się jako Mnich z Chilendaru w przekładzie Krystyny Migdalskiej.

Zarówno wówczas, jak i obecnie Paisij przekonująco przemawia nie tylko do przedstawicieli swojego narodu. Recepcja jego tekstu sięga poza historyczne granice Bułgarii. Tak np. nawet w ZSRR, a później w Rosji tłumaczono materiały krytyczne o Historii SB. Przykładem tego jest chociażby przekład pracy B. Angełowa, która powstała w 1985 r. w Sofii w duchu charakterystycznym dla tej epoki. Dlatego wobec wyżej wspomnianej pracy i innych, często obciążonych ideologicznie, badacz zawsze musi być wyjątkowo subtelny i zdystansowany.

Dla nieobciążonej politycznie krytyki rosyjskiej, zwłaszcza tej opozycyjnej, Historia $S B$ jest zjawiskiem ciekawym z powodu obiektywnych interpretacji Paisija. Jak wiemy, poszukiwanie prawdy historycznej stawiał on za główny cel badawczy i nie zajmował się demagogią i propagandą polityczną (to zjawisko w rozumieniu współczesnym jeszcze nie funkcjonowało w czasach jego życia). Jeszcze na początku rozdziału Историческо събрание за българския народ pisze:

Изпърво откъде са произлезли българите, понеже ни се случи много пъти да прочитаме различни ръкописни и печатни истории, които русите и московците са издали отделно за славянския род: откъде са повели своето племе и после как се отделили от тях българите и дошли, та се заселили в българската земя [Паисий Хилендарски 1989: 42].

Wyraźnie widzimy, że autor rozdziela Rusów i Moskowitów (spadkobiercami spuścizny tych narodów odpowiednio są Ukraińcy i Rosjanie), tym samym pokazując odrębność tych narodów. Dzięki Paisijowi został potępiony mit o wspólnym dziedzictwie kulturalno-narodowym Ukrainy i Rosji, którego echo brzmi do dziś, i stereotyp o dominacji narodu rosyjskiego i jego kultury nad innymi narodami słowiańskimi. Obecnie uwagi Paisija mają nieocenione znaczenie dla historii Ukrainy i Rosji, zwłaszcza na tle wojennych konfliktów.

${ }^{3}$ Cytowanie wypowiedzi Sławejkowa według rosyjskiego przekładu pracy Angełowa, co świadzcy o zainteresowaniu tym tematem w kręgach rosyjskiej krytyki literackiej. 
Moim zdaniem jedną z najciekawszych cech tekstu jest to, że autor nie ogranicza się tylko do opisywania historii swojego narodu, że zasięg jego badań obejmuje skalę ogólnosłowiańską. Sam wyraz славянобългарска już potwierdza panslawistyczne nastawienie. Autor stara się uporządkować informację o Słowianach, bada genezę ogólnosłowiańską, historię Bułgarii zestawia z historią Serbii, podkreśla sakralne, biblijne pochodzenie Słowian.

Paisij pragnął wykreować, odnaleźć swój naród, więc spotkał się z greckimi i serbskimi zarzutami, jakoby Bułgarzy nie mogli mieć swojej historii. Grecki badacz Wasilis Maragos twierdzi:

...тези подигравки подбуждат Паисий да доведе докрай изследването си на българската история и да напише своята «Славянобългарска история» с цел да потърси алтернативна, но също така славна генеалогия на българите, да подчертае връзките им с останалите славянски народи... [Марагос 2012: 79].

Ale Paisij wyraźnie wskazuje na pierwszeństwo Bułgarów w kwestii piśmiennictwa i popularyzacji prawosławia. To miało fundamentalne znaczenie dla odrodzenia dumy narodowej:

Така българите по-рано от всички славянски народи приели православието, по-рано имали свой патриарх и цар и започнали да четат на своя език [Паисий Хилендарски 1989: 101].

\section{Bułgarscy badacze N. Aretow i N. Czernokożew podkreślają:}

$\mathrm{C}$ «История славянобългарска» на Паисий Хилендарски започва основната тенденция, която поставя българите в координатната система на Библията и търси връзките с голямата общност на християнската цивилизация [Аретов, Чернокожев 2008].

W celu poszukiwania etnogenezy Bułgarów i pozostałych narodów słowiańskich Paisij nawiązuje do Biblii, interpretuje osiedlenie się plemion Sema, Chama i Jafeta w różnych częściach świata. Jak na swoje czasy autor Historii SB znakomicie się orientował w geografii, ponieważ przytacza nazwy miast i narodów z różnych kontynentów. Interpretując fenomen Wieży Babel jest zwolennikiem biblijnej teorii powstania języków.

Ciekawie Paisij opisuje toponim Moskwa, wywodząc go od imienia syna Jafeta Moschosa. Nie jest to oficjalna wersja powstania toponimu, mamy tu więc wpływ tzw. etymologii ludowej.

Natomiast szczegółowo i prawdziwie autor opisuje pojawienie się plemion zachodniosłowiańskich nad Wisłą i Morawą, co jest wyjątkowo ważne dla narodu polskiego i jego historiografii:

Римляните ги подчинили под властта и вярата на папата. Тия славяни са от един род и език с българите [Паисий Хилендарски 1989: 45].

Etnonim болгари natomiast wywodzi od nazwy rzeki Wołga (Болга), ponieważ właśnie tam osiedliły się pierwotnie plemiona protobułgarskie. Natomiast 
ze względu na aktualny stan wiedzy (rzeka Wołga płynie z Północy na Południe i wpada do Morza Kaspijskiego) opis Wołgi u Paisija jest jednak mylący:

...pека Болга, която тече от юг към север през Московската държава и се влива в Океанморе [Паисий Хилендарски 1989: 45].

Paisij nie zawsze też podaje dokładne daty wydarzeń historycznych, np. w opisie chrztu Rusi Kijowskiej (poprawna data to 988 r.), ale ważny, przede wszystkim, dla narodu ukraińskiego jest sam fakt, odnotowany następująco:

...руският и киевски княз Владимир приел светото кръщение в 1008 г. [Паисий Хилендарски 1989: 101].

Jeszcze jedna uwaga Wasilisa Maragosa na temat rozbieżności chronologicznej:

Според „Славянобългарска история” българите се настаняват на южните брегове на Дунав не в края на VII в., а още през епохата на император Валенций, в края на IV в. [Марагос 2012: 108].

Fakty budzące wątpliwości można wytłumaczyć celem, który stawiał sobie Paisij. Cel jego dzieła i jego znaczenie, jak już wspominałem, to kształtowanie świadomości narodowej, a nie pisanie pracy naukowej na temat historii. Dlatego nie dziwi, że przy opisywaniu wydarzeń czy postaci obserwuje się czasem lekką hiperbolizację. Lekow broni podejścia Paisija w taki sposób:

Той не се бои, че ще бъде упрекнат в субективизъм, защото изгражда своите концепции върху солидни източници [Леков 2003].

Niezależnie od obiektywnych trudności, Paisij stara się być prawdomówny i szczery wobec odbiorców. Jego moralność chrześcijańska nie pozwala mu manipulować historią. Dlatego naśladując średniowieczną tradycję literacką, kończy swoją Historię $S B$ formułą modlitewną. Wyznaje, że wykonał swoją misję na chwałę Chrystusowi i ku pożytkowi swoich rodaków.

Badania autentyczności faktów podanych przez Paisija to wciąż wyzwanie dla naukowców. Wymaga to skupienia nad materiałem historiograficznym i zdystansowania się od emocjonalnej narracji Paisija. Taką pracę podjął Wasil Aprilow. W dobie Bułgarskiego Odrodzenia Narodowego zaobserwował on brak tradycji historiograficznej. Skoro dzieło Paisija uważał za niezbyt obiektywne i wypełnione emocjonalną patetyką, to za swój cel postawił poprawienie jego błędów w celu uwspółcześnienia bułgarskiej historii i potwierdzenia jej autentyczności. Opracował głównie informację o świętych braciach Cyrylu i Metodym, których Paisij przedstawia jako butgarskich apostołów. Aprilow przytoczył argumenty, potwierdzające bułgarskie korzenie Świętych Braci, co z kolei od dawna poddawane jest pod dyskusję. 


\section{Aktualność dzieła i jego najnowsze wydanie}

Zainteresowanie dziełem życia Paisija obserwowano od dawna nie tylko w Bułgarii, ale w całej Europie. Obecnie również aktualna jest postać samego autora, który inspiruje nowe pokolenia.

Na wybitne dzieło Paisija i jego osobowość szczególną uwagę zwrócił jeszcze w zeszłym wieku polski tłumacz Franciszek Korwin-Szymanowski. Jako pierwszy wśród thumaczy wykonał ogromną pracę translatorską i badawczą, związaną z Historia SB. W 1981 r. ukazało się jego thumaczenie Historii słowianobutgarskiej (Warszawa, wydawnictwo Czytelnik). Wydanie zostało zaopatrzone w materiał krytyczny jego autorstwa. Cenne uwagi i komentarze do architekstu były podane w końcowej części wydania. Jest to niemalże jedyna obszerna publikacja w polskiej krytyce literackiej, umożliwiająca recepcję dzieła Paisija.

Najnowsze i najbardziej istotne refleksje krytyczne wobec Historii $S B$ i o jej funkcji znajdujemy w pracach współczesnych polskich badaczy, a mianowicie w publikacjach Elżbiety Solak i Marioli Walczak-Mikołajczakowej. Elżbieta Solak pisze o dziele jako o historii skandalicznej, budzącej polemikę i zainteresowanie w różnych okresach i okolicznościach historycznych. Mimo to badaczka słusznie sakralizuje „książeczkę” Paisija i określa ją następująco: „....sławiąca świetność historycznych przodków i wpajająca dumę z bycia Bułgarem [...] budząc nastroje patriotyczne" [Solak 2009: 130]. Podobnie funkcję przełomowego dzieła przedstawia M. Walczak-Mikołajczakowa.

W powszechnej opinii Historia słowianobułgarska budziła nastroje patriotyczne i świadomość narodową, wywierając ogromny wpływ na współczesnych (o czym świadczą jej licznie zachowane, pieczołowicie przepisywane w kolejnych latach kopie) i ten aspekt jej oddziaływania stanowi najczęstszy przedmiot rozważań historyków i literaturoznawców [Walczak-Mikołajczakowa 2003: 296].

Mimo zainteresowania danym tematem w polskiej krytyce literackiej, ciekawym jest również fakt, że język polski jest jedynym wśród języków słowiańskich, na który została przetłumaczona Historia $S B$, nie licząc przekładu na współczesny język bułgarski. Nie istnieje nawet przekładu serbskiego, mimo iż dzieło zawiera sporo informacji na temat serbskiej historii.

W 1984 r. dzieło ukazało się w niemieckim Lipsku. Tłumaczenia na niemiecki dokonał słynny literaturoznawca i tłumacz Norbert Randow ${ }^{4}$. Swój przekład opatrzył komentarzem naukowym, który był nie tylko pomocą w percepcji tekstu, ale również potwierdził nowatorskie podejście tłumacza do przedstawienia wybitnego dzieła historycznego.

Historia $S B$ została przetłumaczona na inne języki kongresowe: angielski (thumaczenie - Krasimir Kabakcziew, 2000) , francuski (tłumaczenie - Atanas

${ }^{4}$ 250. Jahrestag der Fertigstellung der "Slawobulgarischen Geschichte" von Paissi von Chilendar, 19.06.2012, http://bnr.bg/de/post/100158408/250-jahrestag-der-fertigstellung-der-slawobulgarischen-geschichte-von-paissi-von-chilendar [dostęp: 5.02.2018].

${ }^{5}$ Кражба има - крадччи няма!, 3.02.2016, http://kkabakciev.blogspot.com/2016/02/1980. html (Blog Krasimira Kabakcziewa) [dostęp: 7.12.2017]. 
Popow, wydawca Rafael de Surtis) ${ }^{6}$, hiszpański (tłumaczenie - Francisco Javier J. Galves) ${ }^{7}$. Dopiero w 2003 r. ukazało się pierwsze tłumaczenie dzieła na język grecki (tłumaczenie - Waica Mojsidu-Chani) [Филевска 2012].

Ciekawym jest fakt, że od 2018 r. dzieło Paisija można przeczytać w języku perskim. Utwór ukazał się w kunsztownym opracowaniu graficznym z komentarzem. Tłumaczami dzieła są iraniści, wykładowcy Uniwersytetu Sofijskiego - Iwo Panow i Alireza Purmochammad8.

Historia SB zwykle pojawia się w bogato zdobionych wydaniach, co potwierdza fakt, że jest to jedna z najważniejszych księg bułgarskich. $Z$ okazji 250-ej rocznicy swojego powstania dzieło ukazało się oprawione w drogą włoską skórę, wydrukowane tuszem najwyższej jakości i na papierze najlepszego gatunku [Петрова 2015] i jest rozpowszechniane wśród Bułgarów mieszkających na obczyźnie. Jest dostępne już w Wielkiej Brytanii, Niemczech i USA, tam, gdzie mieszka i pracuje najwięcej Bułgarów. Ta inicjatywa pozwala łączyć rodaków z różnych stron świata.

Aktualność i znaczenie sprawy Paisija wzrasta dziś z powodu kwestii językowej. Dotyczy to nie tylko Bułgarów, ale również innych narodów, wśród których jest dużo migrantów. Spora część takich osób przeżywa tzw. zespół migranta, często pragnie ukryć kraj swego pochodzenia, wyrzeka się języka ojczystego, posługując się obcym. Dlatego poczucie mniejszej wartości z powodu swego pochodzenia Paisij poddaje ostrej krytyce i uważa takich ludzi za niemądrych. Taką opinię stosuje wobec marginalizacji języka ojczystego, ponieważ język jest kodem nacji, więc nie ma żadnych wątpliwości, że słowa: Българино, знай своя род и език! można uznać za motto także dla współczesnych pokoleń.

\section{Bibliografia}

„,История славянобългарска” - на персийски език, 1.02.2018, [brak autora], http://epicenter.bg/ article/-Istoriya-slavyanobalgarska----na-persiyski-ezik/146393/6/0 [dostęp: 23.02.2018].

„История славянобългарска” излезе на френски език, [brak autora], 2.03.2016, https://skif.bg/index. php/knigi/novini/2725-istoriya-slavyanobalgarska-izleze-na-frenski-ezik [dostęp: 7.12.2017].

Ангелов Б., Паисий Хилендарский и его «История славяноболгарская», 2.04.2017, http://www. library.by/portalus/modules/biographies/readme.php?subaction=showfull\&id=1491150218\& archive $=\&$ start_from $=\& u c a t=\&[$ dostęp: 1.12 .2017$]$.

Аретов Н., Чернокожев Н. (2008), Българска литература, Издателство Анубис, София.

Арнаудов М. (1962), Паисий Хилендарски, София.

Вазов И., Епопея на забравените, http://www.slovo.bg/showwork.php3?AuID=14\&WorkI$\mathrm{D}=914 \&$ Level=2 [dostęp: 1.12.2017].

Дринов М. (1871), Отеи Паисий, неговото време, неговата История и учениците му, Периодическо списание, Браила, I, кн. 4, с. 3-26.

${ }^{6}$ „,История славянобългарска” излезе на френски език, 2.03.2016, https://skif.bg/index. $\mathrm{php/knigi/novini/2725-istoriya-slavyanobalgarska-izleze-na-frenski-ezik} \mathrm{[dostęp:} \mathrm{7.12.2017].}$

7 Учени от ЮЗУ „Неофит Рилски” и СУ,, Св. Кл. Охридски” организират международен семинар, 7.10.2010, https://m.struma.com/obshtestvo/vupros-na-deputata-georgi-andonov_12227 [dostęp: 10.12.2017].

${ }^{8}$ „История славянобългарска”- - на персийски език, 1.02.2018, http://epicenter.bg/article/Istoriya-slavyanobalgarska----na-persiyski-ezik/146393/6/0 [dostęp: 23.02.2018]. 
Иванов Й. (1914), Исторія Славьноболгарская, собрана и нареждена Паисіемъ іеромонахомъ в льто 1762, Дьржавна печатница, София.

Игов С. (2002), История на българската литература, Издателство Сиела, София.

Кабакчиев К., Кражба има - крадии няма, „Литературен форум”, брой 2 (425) 5.09-11.09.2000, http://www.slovo.bg/old/litforum/002/kkabak.htm [dostęp: 7.12.2017].

Кражба има - крадичи няма!, 3.02.2016, http://kkabakciev.blogspot.com/2016/02/1980.html [dostęp: 7.12.2017].

Леков Д., Вечната «История славянобългарская», , Български език и литература”, кн. 2/2003, liternet.bg [dostęp: 26.11.2017].

Марагос В. (2012), Паисий Хилендарски и Софроний Врачански, Превод Кирил Топалов, Университетско издателство „Свети Климент Охридски”.

Паисий Хилендарски (1989), Славянобългарска история, [brak autora opracowania], Издателство Български писател, София.

Паисий Хилендарски (2004), История славянобългарска, Препис-белова на Паисиевия автограф, opracowanie/przedmowa prof. B. Dimitrow, Издателство Български бестсельр, София.

Петрова С. „История славянобългарска” - винаги нужната книга, 4.11.2015, http://bnr.bg/ post/100622131/istoria-slavanobalgarska-vinagi-nujnata-kniga [dostęp: 25.11.2017].

Радев И. (2012), История на българската литература през Възраждането, второ допълнително издание, Издателство Абагар, Велико Търново.

Учени от ЮЗУ „Неофит Рилски” и СУ „Св. Кл. Охридски” организират международен семинар, [brak autora], 7.10.2010, https://m.struma.com/obshtestvo/vupros-na-deputata-georgi-andonov_12227 [dostęp: 10.12.2017).

Филевска Б., Факт първият превод на История славянобългарска на гръики, 21.04.2012, http://newsbg.eu/archives/869 [dostęp: 1.12.2017].

Dąbek-Wirgowa T. (1980), Historia literatury bułgarskiej. Zarys, Wydawnictwo Zakład Narodowy im. Ossolińskich, Wrocław.

De Paisij de Hilendar (2004-2005), L'Histoire Slavo-bulgare, Traduction et commentaire, DREA présenté par Athanase Popov, http://www.makedonskatribuna.com/BROJ_24_SLAVOBULGARE.pdf [dostęp: 7.12.2017].

Paisij Chilendarski (1981), Stowianobutgarska historia, tłum. i komentarz F. Korwin-Szymanowski, Wydawnictwo Czytelnik, Warszawa.

Randow N. (1984), Slawobulgarische Geschichte. Von Païssi von Chilendar, Leipzig.

Solak E. (2009), Nowe życie znaków (o patriotyzmie w bułgarskiej kulturze masowej), [w:] Kultury stowiańskie między postkomunizmem a postmodernizmem 1989-2004, red. M. Dąbrowska-Partyka, Wydawnictwo Uniwersytetu Jagiellońskiego, Kraków, s. 119-132.

Szwat-Gyłybowa G. (2011), Paisij Chilendarski/Hilendarski, [w:] Leksykon tradycji bułgarskiej, red. G. Szwat-Gyłybowa, Wydawnictwo Slawistyczny Ośrodek Wydawniczy, Warszawa.

Walczak-Mikołajczakowa M. (2013), Świętość władzy podług mnicha Paisija, „Poznańskie Studia Slawistyczne", nr 5, s. 295-304.

Wladimirow W., 250. Jahrestag der Fertigstellung der "Slawobulgarischen Geschichte” von Paissi von Chilendar, 19.06.2012, http://bnr.bg/de/post/100158408/250-jahrestag-der-fertigstellungder-slawobulgarischen-geschichte-von-paissi-von-chilendar [dostęp: 5.02.2018]. 
Vitaliy Zatylnyy

\title{
THE IMPORTANCE OF SLAVONIC-BULGARIAN HISTORY OF PAISIUS OF HILENDAR FOR THE HISTORIOGRAPHICAL AND LITERARY CRITICS AND HER RECEPTION IN THE DIACHRONIC PERSPECTIVE
}

\begin{abstract}
(Summary)
Formally, Slavonic-Bulgarian History (Istoriya Slavyanobolgarskaya) of Paisius of Hilendar is a manifesto of the era and a source of knowledge for Bulgarians and other Slavic nations. However, the glorification of history and its prominent heroes, presented with the help of emotional rhetoric, indicates the educational and patriotic destiny of the work. Despite some factual inaccuracies, the work has become the second most important book after the Bible for the Bulgarian nation. The author also showed in it interesting facts that arouse discussions in contemporary science. The work cannot be named just a chronicle, because history in it not only enlightens, but is an indispensable foundation for statehood and national identity. The above statement leads to the conclusion that interest in work of Paisius is growing in European society, which underlines the rich past of the Slavs and is a symbol of the struggle of the Bulgarian people for its freedom.
\end{abstract}

Key words: Paisius, history, Slavic, Bulgarian, people, language, reception 